\title{
Polarization extinction ratio and polarization dependent intensity noise in long-pulse supercontinuum generation (Conference Presentation)
}

Chin, Catherine; Engelsholm, Rasmus Dybbro; Moselund, Peter Morten; Feuchter, Thomas; Leick, Lasse; Podoleanu, Adrian; Bang, Ole

\section{Published in:}

Proceedings of SPIE

Link to article, DOI:

$10.1117 / 12.2253478$

Publication date:

2017

Document Version

Publisher's PDF, also known as Version of record

Link back to DTU Orbit

Citation $(A P A)$ :

Chin, C., Engelsholm, R. D., Moselund, P. M., Feuchter, T., Leick, L., Podoleanu, A., \& Bang, O. (2017).

Polarization extinction ratio and polarization dependent intensity noise in long-pulse supercontinuum generation (Conference Presentation). In Proceedings of SPIE (Vol. 10089). [100890L] SPIE - International Society for Optical Engineering. Proceedings of SPIE - The International Society for Optical Engineering https://doi.org/10.1117/12.2253478

\section{General rights}

Copyright and moral rights for the publications made accessible in the public portal are retained by the authors and/or other copyright owners and it is a condition of accessing publications that users recognise and abide by the legal requirements associated with these rights.

- Users may download and print one copy of any publication from the public portal for the purpose of private study or research.

- You may not further distribute the material or use it for any profit-making activity or commercial gain

- You may freely distribute the URL identifying the publication in the public portal 


\title{
Polarization extinction ratio and polarization dependent intensity noise in long-pulse supercontinuum generation (Conference Presentation)
}

\author{
Catherine Chin, NKT Photonics A/S (Denmark); Rasmus Dybbro Engelsholm, DTU Fotonik \\ (Denmark); Peter M. Moselund, Thomas Feuchter, Lasse Leick, NKT Photonics A/S \\ (Denmark); Adrian Podoleanu, Univ. of Kent (United Kingdom); Ole Bang, DTU Fotonik \\ (Denmark)
}

\begin{abstract}
We investigate the polarization of supercontinuum generated in nominally non-birefringent silica photonic crystal fibers over the entire spectrum of the source $(450-2400 \mathrm{~nm})$. We demonstrate that the degree of polarization varies over the spectrum but that some parts of the spectrum show stable polarization extinction ratios (PER) of over 10 $\mathrm{dB}$. We experimentally demonstrate how the spectrally resolved polarization develops with increasing power and along the length of the nonlinear fiber. The experimental results are compared to numerical simulations of coupled polarization states mimicking the experimental conditions. Subsequently, a single-shot pulse-to-pulse polarization dependent relative intensity noise (PD-RIN) was measured and the noise characteristics were analyzed using longtailed and rogue wave statistics. To do this, we used a range of $10 \mathrm{~nm}$ narrow bandpass filters (BPF) between 550 $\mathrm{nm}$ to $2200 \mathrm{~nm}$, and fast photo detectors, to record 800 consecutive pulses. Peaks from these pulses are first extracted, then distribution of their pulse height histogram (PHH) is constructed. Analysis using higher-order moments about the mean (variance, skewness and kurtosis) showed that: (1) around the pump wavelength of $1064 \mathrm{~nm}$, the PD-RIN is lowest, PHH exhibits a Gaussian distribution, and higher order moments are zero, (2) further away from pump, PD-RIN increases in parabolic fashion, PHH follows a left-skewed long-tailed Gamma distribution, and higher-order moments increase. Spectrally, the difference of the PD-RIN in the two orthogonal axes increases with PER.
\end{abstract}

View presentation recording on the SPIE Digital Library: http://dx.doi.org/10.1117/12.2253478.5387835751001 